\title{
Mutậwầsith
}

JURNAL HUKUM ISLAM

\section{PENGARUH DAN PERANAN KYAI DALAM MENGAWAL KERUKUNAN UMAT BERAGAMA DI KOTA TASIKMALAYA}

\author{
Ujang Hidayatulloh \\ Fakultas Syariah Intitut Agama Islam Cipasung Tasikmalaya, Indonesia \\ Email: ujanghidayatulloh@iaic.ac.id
}

\begin{abstract}
Abstrak
Peran Kyai dalam hal sosial keagamaan dan kemasyarakatan sebagian mulai ditinggalkan, karena tergeser dengan pengaruh budaya asing yang tanpa sadar memaksa diikuti, padahal banyak peranan Kyai memiliki nilai-nilai istimewa yang terkandung di dalamnya. Begitu juga Peranan Kiai khususnya di Kota Tasikmalaya sejak berdirinya pemerintahan Kota Tasikmalaya sampai sekarang tidak terlepas dari peranan dan pengaruhnya. Penelitian ini bertujuan untuk mengetahui peranan dan pengaruh Kyai di Kota Tasikmalaya antara lain : 1) Peranan dari Kiai dalam mengawal kerukunan hidup beragama dan hidup bermasyarakat. 2) Faktor pendukung dan penghambat Kyai dalam mengawal kerukunan hidup beragama dan masyarakat. Penelitian ini merupakan penelitian deskriptif analitik dengan pendekatan kualitatif. Subyek penelitian ini adalah Kyai, Pesanteren dan Masyarakat yang berdomisili di Kota Tasikmalaya. Pengumpulan data dilakukan dengan menggunakan metode observasi, wawancara dan dokumentasi. Teknik yang digunakan dalam analisis data adalah reduksi data, display data dan pengambilan simpulan. Hasil penelitian menunjukkan bahwa: 1) Peranan dan pengaruh Kyai dalam mengawal dan memjaga kerukunan hidup beragama dan masyarakat, sebagai tokoh agama, pengelola, elite politik, motivator dan penyedia fasilitas layanan belajar. 2) Faktor pendukung Kyai dalam menjaga kerukunan hidup beragama dan bermasyarakat adalah penerimaan dan kepercayaan dari Masyarakat akan keberadaan Kyai serta adanya dana baik hibah maupun bantuan yang tidak mengikat untuk penyelenggaraan program; sedangkan faktor penghambat adalah kurangnya kepercayaan dari masyarakat dan minusnya perhatian pemerintah.
\end{abstract}

Kata Kunci: Pengaruh, Peranan Kyai, Lintas umat Beragama, Masyarakat, pemerintah

\section{Abstract}

The role of Kyai in social religious and societal is partly abandoned, as it is shifted by the unconsciously forced influence of foreign cultures, whereas many of Kyai's roles have special values contained therein. So also the role of Kiai in particular in the city of Tasikmalaya since the establishment of the city of Tasikmalaya until now not separated from its role and influence. This research aims to determine the role and influence of Kyai in the city of Tasikmalaya, among others: 1) The role of Kiai in controlling the harmony of religious life and community life. 2) The support and inhibitory factor of Kyai in controlling the harmony of religious and community life. This research is a descriptive analytical study with a qualitative approach. The subject of this study is Kyai, Pesanteren and a community domiciled in Tasikmalaya City. Data collection is done using observation methods, interviews and documentation. The techniques used in data analysis are data reduction, data display and sympulsion retrieval. The results showed that: 1) the role and influence of the Kyai in controlling 
Pengaruh Dan Peranan Kyai Dalam Mengawal Kerukunan

Umat Beragama Di Kota Tasikmalaya

and guarding the harmony of religious and societal lives, as religious figures, managers, political elites, motivators and facilities providers of learning services. 2) The supporting factor of Kyai in maintaining the harmony of religious and societal life is the acceptance and trust of the Society of the existence of the Kyai and the funding of both grants and unbinding assistance for the implementation of the program; While the inhibitory factor is lack of trust from the community and the interest of government attention.

Keywords: influence, role of Kyai, cross-religious people, society, and government

\section{PENDAHULUAN}

Kerukunan menurut ejaan bahasa indonesia adalah, akar kata dari kata "rukun" artinya damai, teratur, tertib, tentram, kemudian dimasuki awalan "ke" dan akhiran "an" menjadi kerukunan. Sedangkan "agama" berasal dari bahasa sansakerta yang terdiri dari dua kata yaitu kata "A" artinya tidak dan kata "Gama" artinya kacau. Jadi agama artinya tidak kacau, damai, rukun, tentram dan aman. Kerukunan antar umat beragama adalah hubungan interaksi social diantara para pemeluk agama dengan dilandasi Bhineka Tunggal Ikadengan mengedepankan prinsip toleransi, adil, saling memahami saling menghormati, menghargai diantara sesama umat baik yang seiman maupun yang berbeda keyakinan, sesuai kesetaraan dalam pemahaman, pengalaman dan pendalaman ilmu pengetahuan ajaran agamanya untuk membangun komunikasi dan interaksi soasial serta kerjasama dalam kehidupan bermasyarakat, berbangsa dan bernegara di dalam Negara kesatuan Republik Indonesia (NKRI) yang berdasarkan Pancasila sebagai idiologi bangsa, Undang-Undang Dasar Tahun 1945', Bhineka tunggal ika dan Negara Republik Indonesia di bumi Nusantara.

Kerukunan antar umat beragama menurut pendekatan syariat islam dikenal dengan istilah Ukhuwah Islamiyah, Ukhuwah Ihsaniyah, ukhuwah wathoniyah dan ukhuwah basyariyah merupakan merupakan pilar perekat kebersaman dalam berbangsa dan bernegara sebagai suatu persaudaraan yang memiliki visi misi serta orientasi kebangsaan. Gambaran hubungan antara sesama muslim sebagai satu persaudaraan, dimana antara yang satu dengan yang lain memiliki satu ikatan yang sama. Umat beragama diharapkan mampu memperkuat kerukunan diantara pemeluk agama dengan agamanya. seseorang mampu berfikir dan bertindak cerdas ditengah-tengah masyarakat dan agama menjadi perekat pemersatu umat dalam kehidupan bernegara sebagai rahmatan lil alamin.

Sehingga tercipta stabilitas nasional yang bermartabat dan berdaulat inilah hakekat dari kerukunan antar beragama dan rmasyarakat maka dibentuklah wadah

\footnotetext{
${ }^{1}$ Abu Tholhah, Kerukunan Antar Umat Beragama, (Semarang: IAIN Walisong,1980), hlm.
} 14. 
Pengaruh Dan Peranan Kyai Dalam Mengawal Kerukunan

Umat Beragama Di Kota Tasikmalaya

kerukunan dengan sebutan Forum Kerukunan antar Umat Beraham (FKUB) yang merupakan lembaga untuk membidani kerukunan beragam dan bermasyarakat, baik sesam agama maupun pemeluk lintas agama.

Salah satu masalah yang dihadapi umat beragam dewasa ini adalah rendahnya rasa memilik akan kesatuan dan persatuan sehingga kekuatan mereka menjadi lemah, dan dikhawatirkan terjadi konplik internal. Salah satu sebab rendahnya rasa persatuan dan kesatuan di kalangan umat beragama adalah karena randahnya penghayatan dan pengamalan nilai-nilai pendidikan agaman Persatuan di kalangan antar umat beragama tampaknya belum dapat diwujudkan secara nyata. Perbedaan kepentingan dan golongan seringkali menjadi sebab perpecahan umat dan konplik. Perpecahan itu biasanya diawali dengan adanya perbedaan pandangan dan kepentingan politik sesaat.

Ini salah satu yang menjadi fenomena masalah yang tumbuh subur dan berkembang. Dalam hal furuiyah, sebagian umat Islam sering kali terjebak fanatisme, begitupun terjadi berbedaan antar sekte dan perbedaan keyakinan diantara lintas pemeluk agama. Misalnya terjadi perbedaan pendapat atau penafsiran dalam suatu hukum yang kemudian melahirkan berbagai pandangan atau madzhab. Perbedaan pendapat dan penafsiran pada dasarnya merupakan fenomena yang biasa dan manusiawi sebagai fitrah yang harus disyukuri bukan dipungkiri, karena perbedaan adalah rahmat (ihtilapul ulama rohmatun), Mensikapi perbedaan pendapat adalah upaya memahami berbagai penafsiran dan pemahaman dengan ilmu dan akhlak mulia. Untuk menghindari perpecahan dan konplik peranan Kyai melalui FKUB sangat diharapkan keberadaannya baik sesama keyakinan maupun lintas agama.

Pentingnya peranan Kyai dalam pembentukan karakter dan corak keagamaan, transmisi keilmuan agama, perkembangan pendidikan keagamaan, lembaga sosial dan dakwah, maka diperlukan peran Kyai dan tokoh agama lainya dalam menjaga kerukunan hidup antar umat beragama melalui Ukhuwah Islamiyah dan sebagai salah satu faktor perekat. Penulis melakukan penelitian terhadap Kyai perihal peran dan fungsinya menjadi signifikan mengingat pendekatan empiris mereka memiliki andil dan kontribusi yang sanagt besar dalam pengembangan kerukunan dan berdirinya negera ini.

Terlebih di Kota Tasikmalaya Sebagai Kota santeri yang memiliki jumlah penduduk dengan mayoritas muslim yang terdiri dari berbagai faham/sekte maupun ormas yang berbeda yaitu Nahdlatul Ulama (NU), Muhamadiyah, Persatuan Islam, Al-Wasliyah, Islam Bai'at Wahabi (Salafi), Syiah, ahmadiyah katolik, protestan, Hindu Budha, Kongfuce dan lainnya. Maka kearifan dan keilmuan Kyai menjadi kunci untuk memperkuat kerukunan dalam mengimbangi percepatan 
Pengaruh Dan Peranan Kyai Dalam Mengawal Kerukunan

Umat Beragama Di Kota Tasikmalaya

perkembangan ilmu pengetahuan dan teknologi 4.0 yang tidak dapat kita hindari, dimana pengaruh, pengguna digital dan IT sangat dominan. Dalam situasi kondiosi era ini sejatinya Kyai menjadi panutan (uswatun hasanah) umat ditengah masyarakat yang sangat majemuk dan heterogen terutama diperkotaan, pemikiran idea dan gagasan sangat mengispirasinya terutama dari sisi intelektualitas dan amaliyah (ritual dan sosial) dalam menjawab tantangan modernis dan peminisme, radikalis, transnasional, garis keras serta menciptakan kedamaian diperkotaan.

Karenanya relevan jika penelitian ini mengenai Peranan Kyai di Kota tasikmalaya mendapatakan perhatian dari semua pihak terkait dan pemerintahan untuk dilakukan, baik dari pendekatan perangai, keilmuan dan wawasan maupun dari pendekatan kehidupan serta status sosialnya Kyai. Terutama dari sisi pendekatan kehidupan bermasyarakat, ahlak dan pemikiran dan peranan Kyai, sangat dominan dan signifikan. baik pemikiran keagamaan, maupun berbagai aspek kehidupannya dapat dikenali yang tentunya memiliki rekam jejak cukup baik dalam mengawal Kerukunan Beragama di Masyarakat.

\section{METODOLOGI PENELITIAN}

Metode yang digunakan dalam penelitian ini adalah metode penelitian deskriptif analitis dengam pendekatan kualitatif yaitu penelitian yang menghasilkan data berupa kata-kata (sebutan) tertulis atau lisan dari masyarakat atau perilaku yang dapat diamati.

Adapun pengertian dari metode deskriptif analitis menurut Sugiono adalah: Metode deskriptif adalah "suatu metode yang berfungsi untuk mendeskripsikan atau memberi gambaran dan penjelasan terhadap objek yang diteliti melalui data atau sampel yang telah terkumpul sebagaimana adanya tanpa melakukan analisis dan membuat kesimpulan yang berlaku untuk umum" ${ }^{2}$.

Tujuan dari metode ini untuk menggambarkan dan menjelaskan keadaan sasaran penelitian sesuai situasi dan kondisi dilapangan (apa adanya), yang bertujuan untuk mengangkat fakta, keadaan, variabel dimensi, indicator dari fenomena masalah yang terjadi ketika penelitiandilakukan. Peranan dan pengaruh Kyai dalam mengawal kerukunan hidup beragama dan masyarakat di Kota tasikmalaya berlangsung dan menyajikan data apa adanya ${ }^{3}$. Peneliti dalam

2 Sugiyono, Metode Penelitian Pendidikan Pendekatan Kuantitatif, Kualitatif, R\&D, (Bandung: Alfabeta, 2009), hlm. 2.

${ }^{3}$ Team, A. A. (2012, Januari 28). Anne Ahira. Diambil kembali dari www.anneahira.com: http://www.anneahira.com/penelitiandeskriptifkualitatif.html

Ujang Hidayatulloh 
Pengaruh Dan Peranan Kyai Dalam Mengawal Kerukunan

Umat Beragama Di Kota Tasikmalaya

penelitian ini tidak mengadakan manipulasi atau pengubahan pada variabelvariabel bebas, tetapi menggambarkan suatu kondisi apa adanya ${ }^{4}$.

Subjek penelitian adalah Kyai, Pesantren, Tokoh lintas agama Tokoh masyarakat dan masyarakt, pemerintah terkait serta informan yang dapat memberikan

\section{PEMBAHASAN}

Mewujudkan kerukunan hidup beragama baik antar maupun intern umat beragama, dalam masyarakat plural bukan suatu hal yang mudah. Karena kerukunan hidup antar umat beragama bukanlah hal yang given, melainkan butuh proses, juga karena banyak faktor yang terkait, misalnya faktor sosial, sataus sosial, pendidikan, ekonomi, politik terutama ideologi (madzhab) perbedaan keyakinan dan perbedaan agama. Oleh karena itu dibutuhkan perhatian serius dan kepiawaian dari semua pihak terkait: pemerintahan, Kyai, tokoh lintas Agama budayawan dan masyarakat luas baik secara individu maupun secara kelompok (kolektif).

Zainuddin dalam Mudjia Rahardjo (2006:194) mengatakan, "salah satu hal yang perlu diperhatikan dalam menciptakan kerukunan beragama di Indonesia antara lain adalah pertama, dibutuhkan reorientasi pendidikan agama yang berwawasan luas pada kerukunan umat dan keramahan (rahmah li al-'alamin). Kedua, upaya peningkatan kualitas pendidikan pada masing-masing umat". Pendidikan yang dimaksud adalah pendidikan yang melahirkan akhlaq al-karimah, etika moeral dan susila yang terhormat dengan indikator, adanya sikap jujur, tenggang rasa, dan cinta kasih antar sesama, teloransi, tafahum, tabayyun dan sebagainya. Bukan pendidikan yang hanya sekedar mengedepankan intelek autput tetapi lebih kepada pendidikan kalkter yang melahirkan autcome dan benefid.

Kerukunan bukan hanya bagian dari spirit agama, melainkan juga persoalan hubungan sosial antara kelompok-kelompok yang berbeda agama dan keyakinan di masyarakat, agar senantiasa hidup damai dan rukun, saling membantu satu dengan yang lainnya. Dalam Forum Komunikasi Umat Beragama (FKUB), istilah kerukunan menjadi 'trademerk' tersendiri, selain diskursus tentang agama dan hal-hal yang terkait di dalamnya. Kerukunan hidup beragama merupakan ciri dari potensi integrasi yang terdapat dari adanya kehidupan berbagai agama. Mewujudkan kerukunan hidup beragama atau potensi integrasi ini di Kelurahan Bantarsari, perlu melihat faktor penghambat dan penunjang. Beberapa faktor penghambat

${ }^{4}$ Sukmadinata, Metode Penelitian Pendidikan. (Bandung: Remaja Rosda Karya, 2006), hlm. 8. 
Pengaruh Dan Peranan Kyai Dalam Mengawal Kerukunan

Umat Beragama Di Kota Tasikmalaya

kerukunan hidup beragama di Kelurahan Bantarsari, antara lain: warisan politik imperialis, fanatisme dangkal, sikap sentimen, cara-cara agresif dalam penyebaran agama, pengaburan nilai-nilai ajaran agama antara satu agama dengan yang lain, maupun ketidak matangan dan ketertutupan penganut agama itu sendiri. Bahkan, karena masih kuatnya kultur patriarkal.

Sedangkan, beberapa faktor pendukung dalam upaya kerukunan hidup beragama di Kelurahan Bantarsari, yaitu adanya nilai gotong-royong, saling hormat menghormati kebebasan menjalankan ibadah sesuai dengan agamanya, kerja sama di kalangan intern maupun antar umat beragama, kematangan, keterbukaan sikap para penganut agama. Tentu saja, kerukunan hidup beragama masyarakat Kelurahan Bantarsari,yang dicita-citakan untuk masa-masa mendatang bukan sekadar "rukun-rukunan", melainkan kerukunan yang mantap, kerukunan yang otentik, positif, kerukunan melalui pendekatan komunikasi teologis yang saling pengertian. Aspek kerukunan merupakan nilai yang dapat ditemukan dalam ajaran setiap agama maupun dalam aktivitas social ${ }^{5}$. Salah satu elemen masyarakat yang memiliki keterlibatan sangat besar dalam menjaga dan mengawal kerukunan umat beragama salah satunya adalah Kyai (ulama/cendikia).

Istilah Kyai menunjukan kepada seseorang pimpinan di dalam agama Islam. Dhofier mendefinisikan "Kyai sebagai gelar yang diberikan oleh masyarakat terhadap seorang ahli agama Islam yang memiliki atau memimpin pesantren dan mengajar kitab-kitab klasik pada para santrinya". Gelar tersebut dalam masyarakat menunjukkan penghormatan yang tinggi terhadap status sang tokoh agama sehingga memungkinkan Kyai dapat diterima oleh masyarakat dalam melakukan pembaharuan dan dinamika di lingkungannya ${ }^{6}$.

Umumnya di dalam masyarakat istilah Kyai ini ditunjukan kepada pemimpin pondok pesantren, namun lebih dari itu istilah Kyai ini dialamtkan sebagai seseorang pemuka agama atau pemimpin agama Islam yang memiliki keilmuan, pengetahuan serta kharismatik. Dan merupakan salah satu elit lokal serta sebagai tauladan bagi pengikutnya dan masyarakat sekitarnya.

Kyai adalah orang yang memiliki kecakapan dan kecukupan dalam ilmu agama (Islam) plus amal dan akhlak yang sesuai dengan ilmunya. Kyai dikenal sebagai pemimpin pemersatu umat tidak saja dibidang keagamaan, tetapi juga dalam bidang sosial kemasyarakatan. Terjadinya perubahan-perubahan dalam

5 Wawan Arwani, "Kiai Pesantren dan Kontribusinya dalam Mengembangkan Pluralitas Keberagamaan dan Toleransi di Kabupaten Cirebon", Jurnal Edukasi Holistik, Vol. 15, 2014, hlm. 47.

${ }^{6}$ Zamakhsyari Dhofier, Tradisi Pesantren, Studi tentang Pandangan Hidup Kiai, (Jakarta: LP3ES. 1994), hlm. 55. 
Pengaruh Dan Peranan Kyai Dalam Mengawal Kerukunan

Umat Beragama Di Kota Tasikmalaya

masyarakat, baik perubahan sosial, ekonomi, budaya,politik maupun pandangan, biasa melahirkan perubahan atau pergeseran nilai dan norma dalam masyarakat.

Sebagai orang yang memiliki ilmu pengetahuan agama, Kyai juga berperan dalam meningkatkan kerukunan masyarakat. Sudah tentu ini merupakan pola hubungan interaksi sosial yang sehat dan dinamis antara para Kyai kampung dan masyarakat dan tokog lintas agama yang mereka bimbing. Dalam hal ini apabila di dalam masyarakat terjadi perselisihan ataupun pergeseran nilai atau pendapat yang terjadi maka seseorang Kyai selalu menjadi penengah dalam menentukan dan menciptakan kerukunan agar tercipta suasana yang tentram dan rukun dalam masyarakat.

Kyai adalah sosok figur panutan masyarakat yang sangat berpengaruh. Maka kedudukan Kyai harus berada di tengah, Kyai sebagai payung umat yang akan selalu dibuat perlindungan. Semata-mata agar mendapatkan ketentraman dengan memberikan petunjuk dan fatwa-fatwa keagamaan. Berada di tengah artinya Kyai harus bisa menampung seluruh aspirasi umat yang berkaitan dengan persoalan agama. Untuk menyelesaikan berbagai persoalan yang tengah dan telah berkembang di masyarakat, tentu Kyai tidak dapat berdiri sendiri, Kyai harus bekerja sama dengan masyarakat dan pemerintah.

Sedemikian tingginya peran dan pengaruh Kyai bagi masyarakat sekitar, dimana kehidupannya memiliki pengaruh penting terhadap berbagai aspek kehidupan bukan hanya agama tetapi bidang yang lain seperti pertanian, perkembangan seni budaya, sosial ekonomi, sosial politik, dan sebagainya. Dalam Islam, dikarenakan tipe otoritas ini berada "di luar dunia kehidupan rutin dan profan sehari-hari", maka Kyai dipandang mempunyai kelebihan-kelebihan dan kemampuan cukup dan luar biasa membuat kepemimpinannya diakui, disegani secara umum dan tak pernah dibatasi usia, dimana semakin sepuh semakin kharismatik dan dipisepuh oleh semua kalangan Di samping itu para Kyai merupakan sekelompok tertentu dalam masyarakat yang berbeda dengan kebanyakan orang tetapi menjadi elemen yang sangat penting pada masyarakat yang mendefinisikan dan menyatakan persetujuan bersama yang memberi rasa legitimasi dan prinsip-prinsip dasar bagi penyelenggaraan dan kelangsungan hidup masyarakat ${ }^{7}$.

Syariat Islam menjadi diterima dan bisa dianut oleh masyarakat tidak lepas dari peran para Kyai. Nilai-nilai kesetaraan antar golongan, pluralitas, sinkretisme dan kearifan budaya lokal merupakan nilai-nilai yang dibangun oleh para Kyai dalam

7 John L Esposito, Tokoh Kunci Gerakan Islam Kontemporer, terj. Sugeng Hariyanto, dkk, (Jakarta: PT Raja Grafindo Persada, 2002), hlm. 12. 
rangka membumikan ajaran Islam dan kebangsaan serta kebhinnekaan. Demikian halnya dengan tasammuh, ta'awun, tafahum, tabayyun, keadilan dan multikulturalisme yang menjadi nilai luhur bangsa juga dikembangkan dalam Islam melalui para Kyai. Hadirnya lembaga-lembaga pendidikan agama, dan semangat keagamaan baik formal maupun non formal, seperti pesantren, madrasah, masjid, mushalla dan peninggalan-peninggalan lain baik akademik maupun non akademik merupakan bukti bahwa peran Kyai memiliki perhatian pada bidang peradaban dalam rangka membentuk masyarakat yang cerdas dan memiliki pendidikan karakter yang baik sehingga dapat mengurangi kebodohan, kemiskinan, keterbelakangan dan memiliki moralitas yang tinggi supaya mereka dapat mengatasi persoalan sendiri secara mandiri dan dewasa.

Hampir semua informan yang berhasil ditemui oleh peneliti menyatakan bahwa kerukunan umat beragama di Kota Tasikmalaya "kondusif" dan terkendali tidak ada hal-hal yang mengarah pada konflik bernuansa SARA. Kondisi kondusif kerukunan umat beragama Kota Tasikmalaya, ini dikarenakan keterlibatan aktif masyarakat dan Kyai serta pemerintah dalam menciptakan suasana kondusif dalam bingkai kehidupan rukun baik antar maupun lintas umat beragama. Peran Kyai telah memberikan kontribusi nyata terhadap penciptaan kerukunan hidup beragama di Kota Tasikmalaya.

Sebagai pemimpin keagamaan, kiai adalah orang yang diyakini mempunyai otoritas yang besar di dalam masyarakat. Hal ini terjadi karena Kyai dalam Agama Islam adalah tokoh yang dipandang sebagai orang yang ber usaha suci dan dianugerahi berkah. Karena peran Kyai telah memainkan fungsinya sebagai perantara bagi umat beragama dalam memberikan pemahaman kepada masyarakat tentang apa yang terjadi baik di tingkat lokal maupun nasional, kiai diposisikan oleh masyarakat sebagai penerjemah dan memberikan penjelasan dalam konteks agama dan mengklarifikasi berbagai masalah bangsa pada umumnya.

Hal ini terjadi karena Kyai adalah bagian tak terpisahkan dari elite politik, di mana posisi yang strategis dan diklaim mempunyai kekuasaan yang sah untuk mempersatukan umat dalam menghadapi berbagai ancaman yang nyata dari kelompok-kelompok lain. Akan tetapi terkadang masyarakat banyak yang tidak menyadari tentang peran dan kontribusi mereka dengan melupakan dan tidak menjaga apa yang sudah dilakukan oleh para pemuka agama. Bahkan peran sosial yang dilakukan kadang tidak diingat sama sekali, padahal banyak memiliki nilai-nilai yang terkandung di dalamnya. Begitu juga Peran kiai khususnya di, mil Kota Tasikmalaya iki peran yang penting dalam pengembangan sosial keagamaan, antara lain dalam pendidikan, sosial kegamaan, politik, dan dakwah. 
Pengaruh Dan Peranan Kyai Dalam Mengawal Kerukunan

Umat Beragama Di Kota Tasikmalaya

Para Kyai juga dapat dikatakan sebagai kaum intelektual yang memiliki komitmen pada terciptanya pembaharuan dan reformasi yang terus menerus dalam masyarakat muslim dan menunjukan perpaduan yang menarik antara peran lama Kyai dalam masyarakat muslim. Kaum intelektual digambarkan dengan beberapa cara yang berbeda dan seringkali bertentangan. Meskipun berbeda-beda dan seringkali bertentangan. Meskipun berbeda-beda, ada sedikit rasa penerimaan yang samar-samar akan elemen dan unsur terpenting di masyarakat yang mendefinisikan dan menyatakan persetujuan bersama yang memberi rasa legitimasi dan prinsip-prinsip dasar bagi penyelenggaraan dan kelangsungan hidup masyarakat ${ }^{8}$.

Menurut KH. Abdurrahman Wachid yang sering disebut Gus Dur tokoh agama biasanya diperankan oleh Kyai. Kyai adalah dunia yang penuh dengan kerumitan, apabila dilihat dari sudut pandang yang berbeda-beda. Istilah lain dari Kyai sering disebut dengan bindere, nun atau gus (Jawa) ajengan (Tasikmalaya), ceng (Garut), aang (Cianjur) apih (Sukabumi), mbah (Cirebon) dan Tuan guru (mataram) amang (ciamis) dan sebagainya. Itu semua adalah sebutan yang semula diperuntukkan bagi ulama tradisional di Pulau Jawa, walaupun sekarang ini Kiai digunakan secara generik bagi semua ulama, baik tradisional maupun modernis, di Pulau Jawa maupun di luar Jawa.

Gelar sebagai Kyai memiliki definisi yang agak berbeda dengan gelar sebagai ulama. Hal ini terlihat lebih pada konteks. Walaupun kemudian kemampuan pengetahuan agama dari kedua gelar ini dalam tingkatan yang sama, Kyai pada faktanya lebih dipandang tinggi dari ulama. Horikoshi membedakan Kyai dari ulama lantaran pengaruh kharismanya yang luas. Kyai dipercayai memiliki keungggulan baik secara moral maupun sebagai orang alim. Salah satu sifat Kyai yang paling dikagumi dan ditiru oleh para pengikutnya adalah sikap jujur, ikhlas, shabar, kalem terhadap orang lain tanpa menghiraukan status sosial dan kedudukan. Karenanya, Kyai memiliki kedudukan yang tinggi di mata dan hati masyarakat, khususnya masyarakat priayi dan santri. Hal ini menunjukkan bahwa kiai menduduki posisi sentral dalam masyarakat Islam sehingga mampu melakukan tindakan kolektif yang menghubungkan antara kiai dan masyarakat ${ }^{9}$.

Namun demikian, hal tersebut juga dipengaruhi oleh keunggulannya dalam memahami dan melakukan kontekstualisasi dalam masyarakat setempat, berikut dengan permasalahan-permasalahan lokal yang dihadapinya. Kyai dapat saja

\footnotetext{
8 John L Esposito, Tokoh Kunci Gerakan Islam Kontemporer, terj. Sugeng Hariyanto, dkk, (Jakarta: PT Raja Grafindo Persada, 2002), hlm. 12.

${ }^{9}$ Hiroko Horikoshi, Kiai dan Perubahan Sosial. (Jakarta: P3M, 1987), hlm. 211.
} 
menjelaskan persoalan teologi yang rumit pada seorang petani yang awam dalam pendidikan formal maupun agama, namun dengan bahasa yang mudah dan lekat dengan permasalahan yang sedang dihadapinya. Oleh karena itu, ide dan misi yang dibawa oleh Kyai dapat dipahami oleh para petani, nelayan, pedagang, birokrasi dan dapat menjadi solusi permasalahan yang sedang dialami secara mslahat.

Dalam hal peranan dan pengaruh, Kyai adalah seorang ahli dalam komunikasi dalam hal keislaman (agama) kepada massa petani dan kelas bawah, menengah dan kalangan atas. Sebagai sebuah usaha pengembangan sekolah agama maupun umum ia memiliki masa beradaptasi dan mendiami satu tempat tertentu dalam kurun waktu yang lama. Namun, dalam beberapa hal, secara konseptual Kyai tidak juga bergerak hanya sebagai makelar budaya. Diberbagai daerah dalam banyak kasus, Kyai sering berperan kreatif, inovatif dalam perubahan sosial.

Masalah yang dihadapinya adalah bagaimana kebutuhan akan perubahan itu dapat dipenuhi tanpa merusak ikatan-ikatan sosial yang telah ada sebelumnya, melainkan justru dengan memanfaatkan ikatan-ikatan itu sebagai mekanisme perubahan sosial yang diinginkannya ${ }^{10}$. Makelar budaya sebagai peran dari Kyai akan lebih tepat jika dilihat lebih pada satu peranan dari begitu luasnya peranan kiai dalam masyarakatnya. Kyai sebagai makelar budaya akan lebih tepat difahami jika kondisi yang ada adalah bahwa Kyai dalam masyarakat tersebut merupakan tokoh tunggal yang benar-benar menjadi sentral dalam segala aktivitas masyarakat. Namun, tentunya kondisi masyarakat yang seperti ini akan sangat jarang ditemui.

Keberadaan seorang Kyai pada komunitasnya adalah lebih banyak mengisi ruang kosong sebagai implementasi pola kepemimpinan yang berwibawa, dimana hubungan anatara pemimpin dan masyarakatnya saling berhubungan satu sama lain. Dengan model hubungan yang demikian maka Kyai akan menjadi figur sentral, panutan, tokoh kharismatik yang berpengaruh dikomunitasnya. Peranan strategis Kyai dalam politik, Kyai mempunyai banyak keuntungan sosial atas masyarakatnya. Kyai mampu mempengaruhi, memobilisasi, mengarahkan dengan baik terhadap masyarakatnya. Disisi lain, masyarakat sebagai klien maka kepatuhan pada pemimpinnya, Kyainya nyaris tak bersyarat.

Berdasarkan hasil wawancara, observasi, dan dokumentasi yang telah dilakukan terhadap subjek penelitian, maka dapat disajikan data sebagai berikut.

Hasil dari penelitian ini menunjukan pandangan-pandangan masyarakat terhadap pemenuhan hak dan kewajiban kiai dalam menjaga kerukunan hidup beragama sudah berjalan sesuai harapan masyarakat. Masyarakat menilai Kyai mampu menjalankan dua peran yaitu peran Kyai dalam kegiatan sosial dan peran

${ }^{10}$ Ibid., hlm. 107. 
Pengaruh Dan Peranan Kyai Dalam Mengawal Kerukunan

Umat Beragama Di Kota Tasikmalaya

Kyai dalam kegiatan keagamaan. Masyarakat menjadikan kiai sebagai figur yang mampu berpartisipasi dalam menjaga kerukunan. Kyai berinteraksi saat perayaan PHBI, pekerjaan, pemimpin spiritual, memberi kebebasan interen, memberi kebebasan eksteren. Hak dan kewajiban dalam mejalankan fungsi sebagai Kyai dapat berjalan dengan baik jika kiai mengerti perannya.

Persepsi masyarakat terhadap peran Kyai dalam menjaga kerukunan hidup beragama dan bermasyarakat cenderung sangat positif. Hal ini disebabkan karena didukung oleh sebagian besar masyarakat yang berfaham Ahlus Sunnah wal Jamaah annahdliyah, keterlibatan masyarakat secara aktif dalam majlis taklim; dan memiliki pengalaman menjadi santri di pondok pesantren. Peran kiai dalam menjaga kerukunan hidup beragama dan bermasyarakat sebagai tokoh agama, pengelola, elite politik, motivator dan penyedia fasilitas belajar. Kyai (MUI) berperan aktif dalam tugas dan fungsinya sehingga adanya timbal balik dari berbagai pihak. Dalam Pengajian baik bapak-bapak maupun ibu-ibu sudah dijadwalkan oleh MUI se-Kota Tasikmalaya, apabila ditemukan adanya permasalahan di Masjid (DKM) pasti semua DKM melaporkan atau konsul kepada Kyai (ustadz) setempat lebih jauhnya di diskusikan dengan Kyai (MUI).

Adanya koordinasi yang baik dari Kyai kepada bawahannya sehingga tercipta kerja yang harmonis, misalnya terjadi pada saat kesuksesan kegiatan peringatan Mauludan, rajaban (Isra Mi'ra)j di, kemah bersama bawaslu antar umat beragam se-jabar tang dilaksanakan di Kota Tasikmalaya adalah puncaknya pada kegiatan tersebut yang merupakan agenda baik rutin maupuntahunan yang diselenggarakan bawaslu Kota Tasikmalaya

Namun, ada sebagian kecil masyarakat yang memberikan penilaian negatif terhadap peran Kyai dalam pemberdayaan kehidupan beragama, khususnya terkait dengan pemberdayaan dalam aspek keyakinan. Hal ini dimungkinkan bahwa sebagian masyarakat belum mengenal terhadap figure ketokoh Kyai yang sebenarnya, sehingga muncul istilah "kiai dampar" (ulama suu) dan atau (Kyai yang hanya bisa mengajar ngaji di masjid, surau, langgar, dan pesantren) dan "Kiai Mimbar" (artinya Kyai yang terbiasa berbicara/pidato melalui mimbar dengan ceramah-ceramahnya). Bahkan, mungkin sebagian masyarakat belum bisa membedakan Kyai yang berstatus sebagai penjaga moral etika dan moral atau Kyai sebagai dukun alternatif.

Namun, sebagian besar masyarakat memberikan penilaian sangat positif kepada peran Kyai, yang dapat diklasifikasikan menjadi dua macam, yakni penilaian yang positif dan penilaian sangat positif. Yang menjadi faktor pendukung kiai dalam menjaga kerukunan hidup beragama dan bermasyarakat adalah penerimaan dan kepercayaan dari warga belajar akan keberadaan Kyai tersebut serta adanya dana 
Pengaruh Dan Peranan Kyai Dalam Mengawal Kerukunan

Umat Beragama Di Kota Tasikmalaya

bagi penyelenggaraan program, sedangkan faktor penghambat adalah kurangnya kepercayaan dan egoistic dari masyarakat.

\section{SIMPULAN}

Dari hasil penelitian tentang peran kiai dalam menjaga kerukunan hidup beragama dan bermasyarakat, penulis menyimpulkan beberapa hal diantaranya adalah sebagai berikut:

Kyai telah memainkan fungsinya sebagai perantara bagi umat beragama dalam memberikan pemahaman kepada masyarakat tentang apa yang terjadi baik di tingkat lokal maupun nasional, kiai diposisikan oleh masyarakat sebagai penerjemah dan memberikan penjelasan dalam konteks agama dan mengklarifikasi berbagai masalah bangsa pada umumnya. Hal ini terjadi karena Kyai adalah bagian dari elite politik, di mana posisi yang strategis dan diklaim mempunyai kekuasaan yang sah untuk mempersatukan umat dalam menghadapi berbagai ancaman yang nyata dari kelompok-kelompok lain untuk menjaga kerukunan hidup beragama dan bermasyarakat.

Hal tersebut bisa dilihat dari pandangan-pandangan masyarakat terhadap peran dan pengaruh Kyai dalam menjaga kerukunan hidup beragama dan bermasyarakat sudah berjalan sesuai harapan masyarakat dan memberi penilaian yang positif terhadap peran tersebut. Masyarakat menilai kiai mampu menjalankan dua peran yaitu peran Kyai dalam kegiatan sosial dan peran kiai dalam kegiatan keagamaan. Peran Kyai telah memberikan kontribusi nyata terhadap penciptaan kerukunan hidup beragama dan bermasyarakat di Kota Tasikmalaya Faktor pendukung Kyai dalam menjaga kerukunan hidup beragama dan bermasyarakat adalah penerimaan dan kepercayaan dari warga belajar dan masyarakat akan keberadaan Kyai tersebut serta adanya dana baik anggaran pemerintah maupun sumbangan tak mengikat bagi penyelenggaraan program. Sedangkan faktor penghambat adalah kurangnya kepercayaan dari masyarakat.

Berdasarkan hasil penelitian dan melihat kenyataan yang ada, maka dengan kerendahan hati penulis mengajukan saran yang paling tidak saran ini bisa dijadikan sebagai informasi atau bahan pertimbangan tentang peran kiai dalam menjaga kerukunan hidup beragama dan bermasyarakat, yaitu diharapkan kepada generasi muda penerus perjuangan (khususnya masyarakat Kota Tasikmalaya) dapat memelihara dan melestarikan kerukunan antar umat lintas agama dan masyarakat pada warganya, supaya terjalin sebuah keharmonisan, kedamaian dalam bermasyarakat. 
Pengaruh Dan Peranan Kyai Dalam Mengawal Kerukunan

Umat Beragama Di Kota Tasikmalaya

\section{DAFTAR PUSTAKA}

Arwani, Wawan. (2014). Kiai Pesantren dan Kontribusinya dalam Mengembangkan Pluralitas Keberagamaan dan Toleransi di Kabupaten Cirebon. Dalam Jurnal Edukasi Holistik, vol. 15. (1), 37 halaman. Tersedia: dihttp://syekhnurjati.ac.id/holistik/ article/html. (diunduh 3 April 2018).

Dhofier, Zamakhsyari. 1994. Tradisi Pesantren, Studi tentang Pandangan Hidup Kiai. Jakarta: LP3ES.

Esposito, John. L. 2002. Tokoh-tokoh Gerakan Islam Kontemporer. terj. Sugeng Hariyanto. Jakarta: PT Raja Grafindo Persada.

Hadi, Sutrisno. 1993. Metodologi Research. Yogyakarta: Fakultas Psikologi UGM.

Horikoshi, Hiroko. 1987. Kiai dan Perubahan Sosial. Jakarta: P3M.

Sugiyono. 2009. Metode Penelitian Pendidikan Pendekatan Kuantitatif, Kualitatif, R\&D. Bandung: Alfabeta.

Sukmadinata. 2006. Metode Penelitian Pendidikan. Bandung: Remaja Rosda Karya. Surachmad, Winarno. 2003. Pengantar Penelitian IImiah. Bandung: Tarsito.

Suryabrata, Sumadi. 1992. Metodologi Penelitian. Jakarta: Rajawali Press.

Team, A. A. (2012). Anne Ahira. Diambil kembali dari www.anneahira.com.http://www.anneahira.com/penelitiandeskriptifkualita tif.html

Tholhah, Abu. 1980. Kerukunan Antar Umat Beragama. Semarang: IAIN Walisonngo. 